\title{
An autochthonous case of Zika due to possible sexual transmission, Florence, Italy, 2014
}

G Venturi $^{1}$, L Zammarchi ${ }^{23}$, C Fortuna ${ }^{1}$, ME Remoli ${ }^{1}$, E Benedetti ${ }^{1}$, C Fiorentini $^{1}$, M Trotta $^{3}$, C Rizzo $^{4}$, A Mantella $^{2}$, G Rezza $^{1}$, A Bartoloni ${ }^{23}$

1. Department of Infectious, Parasitic and Immune-Mediate Diseases, Istituto Superiore di Sanità, Rome, Italy

2. Clinica Malattie Infettive, Dipartimento di Medicina Sperimentale e Clinica, Università degli Studi di Firenze, Florence, Italy

3. SOD Malattie Infettive e Tropicali, Azienda Ospedaliero-Universitaria Caeggi, Florence, Italy

4. National Center for Epidemiology and Health Promotion, Istituto Superiore di Sanità, Rome, Italy.

Correspondence: Alessandro Bartoloni (alessandro.bartoloni@unifi.it)

Citation style for this article:

Venturi G, Zammarchi L, Fortuna C, Remoli M, Benedetti E, Fiorentini C, Trotta M, Rizzo C, Mantella A, Rezza G, Bartoloni A. An autochthonous case of Zika due to possible sexual transmission, Florence, Italy, 2014. Euro Surveill. 2016;21(8):pii=30148. DOI: http://dx.doi.org/10.2807/1560-7917.ES.2016.21.8.30148

Article submitted on 16 February 2016 / accepted on 25 February 2016 / published on 25 February 2016

We report a case of Zika virus infection imported in Florence, Italy ex-Thailand, leading to a secondary autochthonous case, probably through sexual transmission. The two cases occurred in May 2014 but were retrospectively diagnosed in 2016 on the basis of serological tests (plaque reduction neutralisation) performed on stored serum samples. Our report provides further evidence that sexual transmission of Zika virus is possible.

\section{Case reports}

At the beginning of May 2014, an Italian man is his early 30 s (patient 1) returned to Florence, Italy, after a 10-day holiday in Thailand. On the day after his arrival, he developed a confluent maculopapular rash, on the face, trunk, arms, and legs, with fever (maximum temperature $38^{\circ} \mathrm{C}$ ), conjunctivitis, and frontal headache with retroocular pain.

Four days later, patient 1 was admitted to the Infectious and Tropical Diseases Unit of the Florence Careggi University Hospital. Blood tests revealed leucopenia (3,000 cells/ $\mu \mathrm{L}$; reference: 4,000-10,000/ $\mu \mathrm{L}$ ) while creatinine, platelet count and transaminases were normal. Serological investigation two days after (i.e. 6 days after symptoms onset), showed past exposure to measles and parvovirus, negative results for human immunodeficiency virus (HIV) 1-2 Ab/Ag and chikungunya IgM, a positive result for dengue virus (DENV) IgM, and negative results for DENV IgG, as well as DENV NS1 Ag (Table).

The symptoms subsequently rapidly resolved (total duration of fever and rash: 6 days) and he was discharged nine days after admission with a probable diagnosis of DENV infection.

Perifocal vector control activities (including spraying adult mosquitoes and destruction of larval breeding sites) were implemented the day after the availability of DENV IgM positive results, around the patient's residence and workplace, even though the period of activity of Aedes albopictus in Italy is usually considered to start in June and end in October [1]. A second and third blood test using enzyme-linked immunosorbent assay (ELISA), performed 38 and 109 days after symptoms onset, showed DENV IgG seroconversion and IgM negativisation in the third sample.

Nineteen days after the onset of symptoms in patient 1 , his girlfriend (patient 2), who was in her late $20 \mathrm{~s}$ developed diffuse pain, associated to both wrists and oedema on fingers of each hand, maculopapular rash on the trunk, arms, and legs, without fever. Four days later she was evaluated at the outpatient facility of the same hospital. Patient 2 had not travelled to tropical areas during the previous year. Blood tests performed on the next day ( 5 days after her symptoms started) showed normal white blood cells and platelet count, normal C-reactive protein, creatinine, transaminases, and undetectable beta-human chorionic gonadotropin (HCG). The patient had IgG antibodies against cytomegalovirus, Epstein-Barr virus, parvovirus and rubella, while she was seronegative for coxsackie $A$, coxsackie $B$, echovirus and DENV (IgG, IgM and NS1 $\mathrm{Ag})$. Serological tests were repeated 39 and 93 days after symptoms onset, respectively, showing a slight positivity for DENV IgG, with IgM and NS1Ag persistently negative (Table).

\section{Retrospective testing of serum samples in 2015 and 2016}

Serum samples of both patients were sent to the Istituto Superiore di Sanità (ISS), Rome, Italy, to perform confirmatory tests (Table) for DENV in June and September 2015, respectively. Plaque reduction neutralisation tests (PRNTs) for DENV gave inconclusive results for both patients: indeed, a $50 \%$ of plaque reduction was 
Laboratory diagnostic test results for dengue virus and Zika virus in two patients, Italy, 2014-2016

\begin{tabular}{|c|c|c|c|c|c|c|c|c|c|}
\hline \multirow[b]{2}{*}{ Patient } & \multirow[b]{2}{*}{$\begin{array}{l}\text { Days from onset } \\
\text { of symptoms }\end{array}$} & \multicolumn{6}{|c|}{ Dengue virus tests } & \multicolumn{2}{|c|}{ Zika virus tests } \\
\hline & & $\begin{array}{l}\text { ELISA } \\
\lg M^{a, b}\end{array}$ & $\begin{array}{l}\text { ELISA } \\
\lg G^{a, b}\end{array}$ & $\begin{array}{l}\text { ELISA } \\
\mathrm{NS}^{\mathrm{a}, \mathrm{b}}\end{array}$ & $\begin{array}{l}\text { ELISA } \\
\operatorname{lgM}^{\mathrm{a}, \mathrm{c}}\end{array}$ & PRNT50 $0^{\mathrm{a}, \mathrm{c}}$ titre & $\begin{array}{l}\text { Real-time } \\
\text { PCR }^{\mathrm{a}, \mathrm{c}}\end{array}$ & PRNT80 $0^{c, d}$ titre & $\begin{array}{l}\text { Real-time } \\
\text { PCR }{ }^{\mathrm{a}, \mathrm{c}}\end{array}$ \\
\hline \multirow{3}{*}{1} & 6 & 24.2 & 5.21 & 2.23 & 2.01 & Neg & Neg & $1: 10$ & Neg \\
\hline & 38 & 12.3 & 16.6 & NC & 2.89 & 1:10 (b.l.) & NC & $\geq 1: 160$ & NC \\
\hline & 109 & 3.23 & 16.4 & 1.84 & 0.87 & 1:10 (b.l.) & NC & $\geq 1: 160$ & NC \\
\hline \multirow{3}{*}{2} & 5 & 1.34 & 4.63 & 3.81 & 0.46 & Neg & Neg & $1: 10$ & Neg \\
\hline & 39 & 3.23 & 15.5 & 2.63 & 0.40 & 1:10 (b.l.) & NC & $\geq 1: 160$ & NC \\
\hline & 93 & 2.51 & 13.2 & 2.77 & 0.34 & 1:10 (b.l.) & $\mathrm{NC}$ & $\geq 1: 160$ & NC \\
\hline
\end{tabular}

b.l.: borderline; ELISA: enzyme-linked immunosorbent assay; NC: not conducted; Neg: negative; PRNT: plaque reduction neutralisation tests; PCR: polymerase chain reaction.

a Test performed in 2014 .

b Tests performed at Azienda Ospedaliero Universitaria Careggi, Florence (Italy). Commercial ELISA (VIRCELL Granada-Spain). Reference values (index): >11: positive; 9-11: inconclusive; <9: negative. Positive results are highlighted in bold.

c Tests performed at the Istituto Superiore di Sanità, Rome (Italy). Commercial IgM-capture ELISA system (Focus Diagnostics dengue Virus IgM Capture, DxSelect, California, US). Reference values (index): >1: positive; $<1$ : negative. Positive results are highlighted in bold. Real-time PCRs were conducted on RNA from serum samples, as described in [29] and [30]. Dengue virus for PRNT: serotype 2 dengue virus (New Guinea B strain). PRNT80 titres $\geq 1: 10$ are considered positive, while PRNT50 titres $\geq 1: 10$ are considered as borderline.

d Test retrospectively performed in 2016 on stored samples. Zika virus for PRNT was kindly provided by Dr Isabelle Leparc-Goffart of the French National Reference Center on Arboviruses in Marseille. The test was performed as described in detail for tick-borne encephalitis virus [31], except that Vero cells were used here.

observed at a 1:10 serum dilution in the second and third serum samples of both patients, while we consider the cut-off for a positive result to be at least $80 \%$ of plaque reduction. Real-time polymerase chain reaction (PCR) tests for DENV, chikungunya virus (CHIKV), and Zika virus (ZIKV), as well as viral isolation in Vero E6 cell, were also performed on samples collected in the acute phase of the disease, all with negative results. Even though DENV PRNT results were inconclusive, patient 1 was counselled as having had dengue infection, given the history of travel and the classical kinetic of IgG and IgM antibodies measured by ELISA, while we were not able to state a definitive diagnosis for patient 2.After ZIKV for PRNT became available to us, the samples were reanalysed in February 2016 (the patients had given their informed consent for further tests), and showed positive results for ZIKV neutralising antibodies, as reported in the Table, with a clear increase in the antibody titre between the first and the second serum sample for both patients.

\section{Background}

ZIKV is an Aedes-borne virus (Flaviviridae family), identified in 1947 in monkey rhesus in Uganda [2,3]. Sporadic human cases were reported in Asia and Africa until 2007, when a ZIKV outbreak occurred in Yap, Micronesia [4]. Subsequently, in October 2013, ZIKV reached French Polynesia, causing a large outbreak [5]. In early 2015, autochthonous cases of ZIKV were reported in Brazil [6], and the virus subsequently spread throughout South America, Central America, and the Caribbean [7-9]. An increasing number of imported cases has been observed in Europe and United States (US) [10-13]. The presumed association of ZIKV infection during pregnancy with increased number of babies born with microcephaly in Brazil [14] convinced the World Health Organization to declare ZIKV a 'Global Emergency of Public Health Concern' in February 2016 [15].

\section{Discussion and conclusions}

Even if ZIKV transmission is mostly vectorial, transplacental and perinatal transmission have been reported; transmission through blood transfusion may also occur [16-18].

Little evidence supports the possibility of ZIKV sexual transmission to date. In December 2013, ZIKV was isolated from the semen of a patient with haematospermia in Tahiti [19]. Further in 2014, ZIKV RNA was detected 62 days after onset of febrile illness in the semen of a person with ZIKV infection, imported into the United Kingdom from the Cook Islands [20]. Sexual transmission from a man who acquired ZIKV infection in Senegal, to his wife was reported in Colorado, US, in 2007 [21], and more recently from a person who had travelled to Latin America, to his partner in Texas [22].

Possible sexual transmission of ZIKV is of particular concern during pregnancy, and specific guidelines for prevention of ZIKV infection through this route have been published recently [23].

Because patient 2 had not travelled to tropical areas during the previous year and had unprotected sexual intercourse with patient 1 during a 20 day period between his return to Italy and her own onset of symptoms, transmission by semen was suggested. Exact dates of sexual intercourse could not be recalled by the patients, who reported several sexual contact events before patient 2's symptom onset. Other transmission modalities (i.e. direct contact with other bodily fluids) 
are unlikely to play a role but may not be completely ruled out.

Transmission through local potentially competent vectors, Ae. albopictus, can likely be excluded considering that patient 1 came back to Italy outside the usual period of vector activity and vector control measures were implemented within eight days after his arrival to Italy, possibly before the estimated extrinsic incubation period could be completed [1,24].

Failure to detect viral RNA even in samples collected few days after the onset of symptoms, and an early detection of ZIKV-specific neutralising antibodies, are consistent with previous reports $[10,19,25]$; however, limits in the sensitivity of the real-time PCR method used in this study cannot be definitively excluded. Serological test results confirm the broad cross-reactivity between DENV and ZIKV. With respect to PRNT results, borderline results for DENV are likely to be due to a low degree of residual cross-reactivity which may not be eliminated even using this test, which is considered highly specific. Another possible limit of our study consists in the fact that only serotype 2 DENV PRNT could be performed; however, this is not likely to affect the interpretation of the results, which clearly show a pattern consistent with ZIKV infection.

Current evidence supports the combined use of PCR and serological tests for the diagnosis of ZIKV infection. PCR can be positive in early serum and saliva samples ( 8 days after symptoms onset), with saliva showing higher detection rates, while PCR on urine seems to enlarge the window of detection of ZIKV RNA up to cazo days after symptoms onset $[26,27]$. Five days after disease onset, serological investigations can be conducted by detection of ZIKV-specific IgM antibodies and confirmation by neutralisation [28].

In conclusion, we provide additional evidence for sexual transmission of ZIKV. Further studies are needed to estimate the probability of sexual transmission and its role as a secondary route of transmission of ZIKV in epidemic and non-epidemic areas.

\section{Conflict of interest}

None declared.

\section{Authors' contributions}

Wrote the manuscript: LZ, GR, GV, AB; performed laboratory investigations: $\mathrm{AM}, \mathrm{CF}, \mathrm{MER}, \mathrm{EB}, \mathrm{CF}, \mathrm{GV}$; revised the manuscript: GR, MT, CR; managed the patients: LZ, MT.

\section{References}

1. Ministero della salute. Direzione Generale della Prevenzione Sanitaria, Ufficio V, Malattie Infettive e Profilassi

Internazionale ex-DGPREV. Sorveglianza dei casi umani di Chikungunya, Dengue, West Nile Disease ed altre arbovirosi e valutazione del rischio di trasmissione in Italia - 2015. Circolare
16 giugno 2015. Italian. Available from: http://www.epicentro. iss.it/problemi/westNile/pdf/Circolare_arbovirosi_2015.pdf.

2. Dick GW, Kitchen SF, Haddow AJ. Zika virus. I. Isolations and serological specificity.Trans R Soc Trop Med Hyg. 1952;46(5):509-20. DOI: 10.1016/0035-9203(52)90042-4 PMID: 12995440

3. Dick GW. Zika virus. II. Pathogenicity and physical properties. Trans R Soc Trop Med Hyg. 1952;46(5):521-34. DOI: 10.1016/0035-9203(52)90043-6 PMID: 12995441

4. Hayes EB. Zika virus outside Africa.Emerg Infect Dis. 2009;15(9):1347-50. DOI: 10.3201/eid1509.090442 PMID: 19788800

5. Cao-Lormeau VM, Roche C, Teissier A, Robin E, Berry AL, Mallet HP, et al. Zika virus, French polynesia, South pacific, 2013. Emerg Infect Dis. 2014;20(6):1085-6. DOI: 10.3201/ eid2006.140138 PMID: 24856001

6. Zanluca C, de Melo VCA, Mosimann ALP, Dos Santos GIV, Dos Santos CND, Luz K. First report of autochthonous transmission of Zika virus in Brazil.Mem Inst Oswaldo Cruz. 2015;110(4):56972. DOI: 10.1590/0074-02760150192 PMID: 26061233

7. Musso D, Cao-Lormeau VM, Gubler DJ. Zika virus: following the path of dengue and chikungunya?Lancet. 2015;386(9990):2434. DOI: 10.1016/S0140-6736(15)61273-9 PMID: 26194519

8. European Centre for Disease Prevention and Control (ECDC). Rapid Risk Assessment. Zika virus infection outbreak, Brazil and the Pacific region. Stockholm: ECDC; 25 May 2015 Available from: http://ecdc.europa.eu/en/publications/ Publications/rapid-risk-assessment-Zika\%2ovirussouthamerica-Brazil-2015.pdf

9. Fauci AS, Morens DM. Zika Virus in the Americas--Yet Another Arbovirus Threat.N Engl J Med. 2016;374(7):601-4. DOI: 10.1056/NEJMp1600297 PMID: 26761185

10. Zammarchi L, Tappe D, Fortuna C, Remoli ME, Günther $\mathrm{S}$, Venturi G, et al. Zika virus infection in a traveller returning to Europe from Brazil, March 2015. Euro Surveill. 2015;20(23):21153. DOI: $10.2807 / 1560-7917 . E S 2015 \cdot 20.23 \cdot 21153$ PMID: 26084316

11. McCarthy M. First US case of Zika virus infection is identified in Texas.BMJ. 2016;352:i212. DOI: 10.1136/bmj.i212 PMID: 26762624

12. Maria AT, Maquart M, Makinson A, Flusin O, Segondy M, Leparc-Goffart I, et al. Zika virus infections in three travellers returning from South America and the Caribbean respectively, to Montpellier, France, December 2015 to January 2016. Euro Surveill. 2016;21(6):30131. DOI: 10.2807/1560-7917. ES.2016.21.6.30131 PMID: 26898198

13. O'Dowd A. UK records four cases of Zika virus in past six weeks.BMJ. 2016;352:i875. DOI: 10.1136/bmj.i875 PMID: 26868672

14. European Centre for Disease Prevention and Control (ECDC). Rapid risk assessment: Microcephaly in Brazil potentially linked to the Zika virus epidemic. Stockholm: ECDC; 25 Nov 2015. Available from: http://ecdc.europa.eu/en/publications/_ layouts/forms/Publication DispForm.aspx?List=4f55ad 51 4aed-4d32-b960-af70113dbb9o\&ID=1407\#sthash.Blacezic. dpuf

15. World Health Organization (WHO). WHO Director-General summarizes the outcome of the Emergency Committee regarding clusters of microcephaly and Guillain-Barré syndrome; 1 Feb 2016. [Accessed 23 Feb 2016]. Available from: http://www.who.int/mediacentre/news/statements/2016/ emergency-committee-zika-microcephaly/en/

16. Besnard M, Lastere S, Teissier A, Cao-Lormeau V, Musso D. Evidence of perinatal transmission of Zika virus, French Polynesia, December 2013 and February 2014.Euro Surveill. 2014;19(13):20751. DOI: 10.2807/1560-7917.ES2014.19.13.20751 PMID: 24721538

17. Musso D, Nhan T, Robin E, Roche C, Bierlaire D, Zisou $\mathrm{K}$, et al. Potential for Zika virus transmission through blood transfusion demonstrated during an outbreak in French Polynesia, November 2013 to February 2014. Euro Surveill. 2014;19(14):20761. DOI: 10.2807/1560-7917. ES2014.19.14.20761 PMID: 24739982

18. Center for Infectious Disease Research and Policy (CIDRAP). Brazil confirms blood-transfusion Zika; PAHO calls for global support. Minneapolis: CIDRAP; 2016. [Accessed o5 Feb 2016]. Available from: http://www.cidrap.umn.edu/newsperspective/ 2016/02/brazil-confirms-blood-transfusion-zika-paho-callsglobal-support

19. Musso D, Roche C, Robin E, Nhan T, Teissier A, Cao-Lormeau VM. Potential sexual transmission of Zika virus.Emerg Infect Dis. 2015;21(2):359-61. DOI: 10.3201/eid2102.141363 PMID: 25625872 
20. Atkinson B, Hearn P, Afrough B, Lumley S, Carter D, Aarons EJ, et al. Detection of Zika virus in semen. Emerg Infect Dis. 2016;22(5). DOI: 10.3201/eid2205.160107

21. Foy BD, Kobylinski KC, Chilson Foy IL, Blitvich BJ, Travassos da Rosa A, Haddow AD, et al. Probable non-vector-borne transmission of Zika virus, Colorado, USA. Emerg Infect Dis. 2011;17(5):880-2. DOI: 10.3201/eid1705.101939 PMID: 21529401

22. McCarthy M. Zika virus was transmitted by sexual contact in Texas, health officials report.BMJ. 2016;352:i720. DOI: 10.1136/ bmj.i720 PMID: 26848011

23. Oster AM, Brooks JT, Stryker JE, Kachur RE, Mead P, Pesik NT, et al. Interim Guidelines for Prevention of Sexual Transmission of Zika Virus - United States, 2016. MMWR Morb Mortal Wkly Rep. 2016;65(5):120-1. DOI: 10.15585/mmwr.mm6505e1 PMID: 26866485

24. Wong PS, Li MZ, Chong CS, Ng LC, Tan CH. Aedes (Stegomyia) albopictus (Skuse): a potential vector of Zika virus in Singapore.PLoS Negl Trop Dis. 2013;7(8):e2348. DOI: 10.1371/ journal.pntd.0002348 PMID: 23936579

25. Charrel RN, Leparc-Goffart I, Pas S, de Lamballerie X, Koopmans M, Reusken C. State of knowledge on Zika virus for an adequate laboratory response [Submitted]. Bull World Health Organ. E-pub: 10 Feb 2016.

26. Musso D, Roche C, Nhan TX, Robin E, Teissier A, Cao-Lormeau VM. Detection of Zika virus in saliva.J Clin Virol. 2015;68:53-5. DOI: 10.1016/j.jcv.2015.04.021 PMID: 26071336

27. Gourinat AC, O'Connor O, Calvez E, Goarant C, DupontRouzeyrol M. Detection of Zika virus in urine.Emerg Infect Dis. 2015;21(1):84-6. DOI: 10.3201/eid2101.140894 PMID: 25530324

28. European Centre for Disease Prevention and Control (ECDC). Zika virus infection: Factsheet for health professionals.

Factsheet for health professionals. Stockholm: ECDC; 12 Feb 2016. Available from: http://ecdc.europa.eu/en/healthtopics/ zika_virus_infection/factsheet-health-professionals/Pages/ factsheet_health_professionals.aspx\#sthash.Ovu33Mb6.dpuf

29. Drosten C, Göttig S, Schilling S, Asper M, Panning M, Schmitz $\mathrm{H}$, et al. Rapid detection and quantification of RNA of Ebola and Marburg viruses, Lassa virus, Crimean-Congo hemorrhagic fever virus, Rift Valley fever virus, dengue virus, and yellow fever virus by real-time reverse transcription-PCR. J Clin Microbiol. 2002;40(7):2323-30. DOI: 10.1128/JCM.40.7.23232330.2002 PMID: 12089242

30. Lanciotti RS, Kosoy OL, Laven JJ, Velez JO, Lambert AJ, Johnson AJ, et al. Genetic and serologic properties of Zika virus associated with an epidemic, Yap State, Micronesia, 2007. Emerg Infect Dis. 2008;14(8):1232-9. DOI: 10.3201/ eid1408.080287 PMID: 18680646

31. Venturi G, Mel R, Marchi A, Mancuso S, Russino F, Pra GD, et al. Humoral immunity and correlation between ELISA, hemagglutination inhibition, and neutralization tests after vaccination against tick-borne encephalitis virus in children. J Virol Methods. 2006;134(1-2):136-9. DOI: 10.1016/j. jviromet.2005.12.010 PMID: 16458368

\section{License and copyright}

This is an open-access article distributed under the terms of the Creative Commons Attribution (CC BY 4.0) Licence. You may share and adapt the material, but must give appropriate credit to the source, provide a link to the licence, and indicate if changes were made.

This article is copyright of the authors, 2016. 